\title{
ANALISIS PENGARUH PELATIHAN DAN IKLIM ORGANISASI TERHADAP KINERJA UKM
}

\author{
Janatul Husnah; Tatiek Nurhayati
}

Magister Manajemen, Universitas Semarang., Semarang,Indonesia

\begin{tabular}{l} 
Info Artikel \\
\hline Sejarah Artikel: \\
Diterima \\
Disetujui \\
Dipublikasikan \\
\hline Keywords: \\
Performance; \\
training;Organizational \\
Climate; Innovation \\
\hline
\end{tabular}

\begin{abstract}
Abstrak
Tujuan dari penelitian ini adalah untuk mengetahui pengaruh pelatihan terhadap kinerja, iklim organisasi terhadap kinerja, pelatihan terhadap inivasi, iklim organisasi terhadap inovasi, inovasi terhadap kinerja dan pelatihan terhadap iklim organisasi. Metode yang digunakan dalam penelitian ini adalah metode explanatory yaitu menjelaskan hubungan antara variable independent dan dependent serta di pengaruhi oleh variable intervening. Metode pengumpuloan data dengan menggunakan survey (koesioner) yang melibatkan 134 orang pelaku UKM fashion di Kota Semarang. Alat analisis yang digunakan dalam penelitian ini adalah SEM (Amos ). Hasil penelitian menunjukan bahwa, pelatihan dan iklim organisasi berpengaruh positif dan signifikan terhadap kinerja dan inovasi, selanjutnya inovasi berpengaruh positif juga terhadap kinerja dan pelatihan berpengaruh positif terhadap iklim organisasi. Hasil lain yang dapat dilihat dari penelitian ini bahwa Inovasi tidak dapat memdiasi pelatihan terhadap kinerja namun iklim organissi terhadap kinerja. $\mathrm{Ha}$; tersebut disebabkan akrena pelatihan dan inovasi dapat meningkatkan kinerja secara terpisah dan sendiri-sendiri.
\end{abstract}

\section{THE IMPACT OF TRAINNING,AND ORGANIZATIONAL CLIMATE TO SMALLS SCALE ENTERPRISES}

\section{Abstract}

The purpose of this study was to determine the effect of training on performance, organizational climate on performance, training on innovation, organizational climate for innovation, innovation on performance and training on organizational climate. The method used in this study is an explanatory method that explains the relationship between independent and dependent variables and is influenced by intervening variables. The method of collecting data by using a survey (questionnaire) involving 134 people of fashion icon in the city of Semarang. The analytical tool used in this study is SEM (Amos). The results showed that training and organizational climate had a positive and significant effect on performance and innovation, then innovation had a positive effect on performance and training had a positive effect on the organizational climate. Another result that can 
be seen from this study is that innovation cannot improve training on performance but organizational climate for performance. Ha; This is because training and innovation can improve performance separately and individually. 


\section{PENDAHULUAN}

Kinerja merupakan dorongan yang menggerakkan seseorang supaya meningkatkan kepuasan dari pelanggannya, sehingga bisa mewujudkan dan mencapai tujuan yang ditentukan perusahaan. Kinerja seseorang sangat penting karena kinerja merupakan salah satu hal yang menyebabkan dan mendukung perilaku manusia supaya mau berkerja giat dan antusias mencapai hasil yang optimal. Menurut Rivai (2011) karakteristik pekerjaan adalah suatu alat yang digunakan untuk berkomunikasi dengan orang lain agar mereka bersedia untuk mengubah suatu perilaku serta sebagai suatu upaya untuk meningkatkan kesadaran dan kesediaan seseorang menaati semua peraturan perusahaan dan norma-norma sosial yang berlaku, untuk meningkatkan kinerja. Kinerja juga akan berkorelasi dengan inovasi pada perusahaan akan meningkatnya ketepatan waktu, ketepatan produk dalam bekerja sehingga seseorang akan bertanggung jawab atas pekerjaannya. Sumber daya manusia merupakan tokoh sentral dalam organisasi maupun perusahaan. Agar aktivitas manajemen berjalan dengan baik, perusahaan harus memiliki seseorang yang berpengetahuan dan berketrampilan tinggi serta usaha untuk mengelola perusahaan seoptimal mungkin sehingga kinerja meningkat.

Kinerja seseorang merupakan hasil atau prestasi kerja seseorang yang dinilai dari segi kualitas maupun kuantitas berdasarkan standar kerja yang ditentukan oleh perusahaan/kelompok. Kinerja yang baik adalah kinerja yang optimal, yaitu kinerja yang sesuai standar perusahaan/organisasi dan mendukung tercapainya tujuan prusahaan. Perusahaan yang baik adalah organisasi yang berusaha meningkatkan kemampuan sumber daya manusianya, karena hal tersebut merupakan faktor kunci untuk meningkatkan kinerja karyawan (Setiyawan dan Waridin, 2006). Peningkatan kinerja akan membawa kemajuan bagi perusahaan untuk dapat bertahan dalam suatu persaingan lingkungan bisnis yang tidak stabil. Oleh karena itu upaya-upaya untuk meningkatkan kinerja karyawan merupakan tantangan manajemen yang paling serius karena keberhasilan untuk mencapai tujuan dan kelangsungan hidup perusahaan tergantung pada kualitas kinerja sumber daya manusia yang ada didalamnya.

Perkembangan dunia industri fashion yang meningkat tanpa disadari ternyata juga memberikan peningkatan pada animo masyarakat dalam memilih fashion yang diinginkan, baik dalam memilih jenis-jenis baju, celana, hijab dan lain sebagainya. Sehingga perusahaan memiliki strategi tersendiri dalam menarik konsumen yang potensial untuk loyal terhadap produk yang mereka tawarkan. Hal ini menuntut para perusahaan agar selalu merancang fashion yang lebih kreatif dan inovatif agar tidak tenggelam dalam persaingan bisnis . Industri fashion di Indonesia saat ini sudah maju dan terus berkembang.

Dalam industri fashion di Indonesia, produsen dalam negeri dan luar negeri saling bersaing untuk merebut pasar. Sehubungan dengan kondisi ini, mereka mempelajari perilaku konsumen agar kemudian dapat menentukan strategi pemasaran yang baik dan tepat sehingga produknya dapat bersaing dipasar. Salah satu perilaku konsumen yang muncul akibat maraknya produk-produk fashion di pasar adalah perilaku pembelian impulsive (impulse buying behavior). Bagi semua orang berbelanja tentunya menjadi kegiatan atau aktivitas yang sering 
dilakukan dan menyenangkan, khususnya bagi kaum wanita untuk menunjang penampilan atau sebagai identitas diri serta yang berhubungan dengan fashion.

Pendampingan dan pembinanaan yang dilakukan oleh Pemerintah Kota Semarang (Dinas Perindustrian Kota Semarang) terhadap UKM fashion salah satunya meningkatkan sumber daya manusia yaitu pelatihan, menurut Ruky (2003:230) "Pelatihan (training) ialah sebuah proses sistematis untuk mengubah perilaku kerja seorang/sekelompok pegawai dalam usaha meningkatkan kinerja organisasi. Pelatihan terkait dengan keterampilan dan kemampuan yang diperlukan untuk pekerjaan yang sekarang dilakukan. Pelatihan berorientasi ke masa sekarang dan membantu pemilik Usaha untuk menguasai keterampilan dan kemampuan (kompetensi) yang spesifik untuk berhasil dalam pekerjaannya.

Selain itu pembinaan lain yang di lakukan adalah menumbuhkan inovasi dari UKM Fashion di Kota Semarang, Menurut Fontana (2011) inovasi sebagai keberhasilan ekonomi berkat adanya pengenalan cara baru atau kombinasi baru dari cara - cara lama dalam mentransformasi input menjadi output ( teknologi ) yang menghasilkan perubahan besar atau drastis dalam perbandingan antara nilai guna yang dipersepsikan oleh konsumen atas manfaat suatu produk ( barang dan/atau jasa ) dan harga yang ditetapkan oleh produsen. Kedua jenis pembinaan yang dilakukan diharapkan dapat menumbuhkan kinerja yang maksimal, pada akhirnya mampu menumbuhkan produktifitas kerja dari UKM fashion di Kota Semarang.

Perkembangan UKM fashion di Kota Semarang semakin tahun terus meningkat, pada tahun 2017 ini jumlah UKM fashion di bawah binaan Dinas Perindustrian berjumlah 45 UKM dengan masing-masing UKM memiliki karyawan minimal 3 karyawan. Tentu permasalahan dan iklim dalam kelompok terus terjadi, kenyamana dalam kelompok tentu menjadi persoalan tertentu dalam menjalankan usaha. Kenyamanan dalam suatu kelompok yang merupakan salah satu indikator penting dalam meningkatkan kinerja dalam bisnis, terutama bisnis fashion. Menurut Davis dan Newstorm, 2000 Iklim organisasi merupakan penilaian iklim manusia di dalam organisasi, dimana para anggota organisasi melakukan pekerjaan mereka. Iklim organisasi merupakan sebuah konsep yang menggambarkan suasana internal lingkungan organisasi yang dirasakan anggotanya selama mereka beraktivitas dalam rangka tercapainya tujuan organisasi.

Selanjutnya selain dari produktifitas, iklim oragnaisasi juga turut menghambat kinerja dari UKM fashion di Kota Semarang. Iklim organisasi UKM fashion di Kota Semarang sangat dinamis, hal ini dapat dilihat dari sebagian besar kelompok UKM Fashion di Kota Semarang lebih banyak di kelola perorangan dengan jumlah karyawan minimal 3 orang. Berdasarkan hasil wawancara dengan salah satu UKM fahion di Kota Semarang menyampaikan bahwa "sebagian besar anggota UKM fashion belum mau masuk dalam kelompok usaha bersama / Koperasi karena adanya dinamika, sehingga dalam menentukan kebijakan bisnis sangat banyak pertimbangan". Berdasarkan hal tersebut bahwa masih adanya dinamika yang terjadi dalam UKM Fashion di Kota Semarang

Selain dari permasalahan iklim organisasi dapat menghambat, juga datang dari intensitas dan materi yang di sampaikan dalam pelatihan, intensitas 
pelatihan secara kuantitas sudah berjalan baik dalam satu bulan kegiatan pelatihan selalu ada terlaksana, namun permasalahan yang muncul dalam pelatihan adalah muatan yang disampaikan terkadang belum sesuai dengan kebutuhan yang diharapkan dari pelaku UKM fashion di Kota Semarang. Kepala Bidang Industri Kimia dan Tekstil pada Dinas Perindustrian Kota Semarang yang menangani pelatihan menyampaikan " bahwa untuk meningkatkan ketrampilan UKM dengan sering diadakan pelatihan hanya saja pelatihan untuk UKM fashion belum beragam sehingga perlu untuk ditambah baik kuantitas dan kualitas".

Kinerja dari fashion UKM di Kota Semarang, sangat dipengaruhi oleh iklim dalam organisasinya. Menurut Davis (2001) ada dua aspek yang penting yang harus diperhatikan dalam iklim organisasi, yaitu tempat kerja itu sendiri dan perlakuan yang diterima dari manajemen, anggota merasakan bahwa iklim organisasi tertentu menyenangkan bila mereka melakukan sesuatu yang berguna yang memberikan kemanfaatan pribadi. Sebagian besar kelompok di dalam bisnis banyak yang merasa tidak nyaman, dan mendirikan kelompok hanya sebagai wadah untuk mendapatkan bantuan, sedangkan aktulisasinya sendiri-sendiri. Sehingga mayoritas UKM Fashion masih merupakan usaha perorangan yang pengolahannya kurang produktif.

Berdasarkan hasil penelitian Sulaefi (2017) menyatakan pelatihan berpengaruh positif dan signifikan terhadap kinerja, sedangkan Sulotego (2017) menyatakan bahwa iklim organisasi bergengaruh positif terhadap kinerja.

\section{Tujuan Penelitian}

Berdasarkan rumusan masalah diatas, maka dapat di rumuskan tujuan dari penelitian ini adalah : Mendiskripsikan dan menganalisis pengaruh pelatihan UKM terhadap kinerja UKM. Mendiskripsikan dan menganalisis pengaruh iklim organisasi terhadap kinerja UKM. Mendiskripsikan dan menganalisis pengaruh pelatihan terhadap inovasi produk. Mendiskripsikan dan menganalisis pengaruh iklim organisasi terhadap inovasi produk. Mendiskripsikan dan menganalisis pengaruh inovasi terhadap kinerja UKM. Mendiskripsikan dan menganalisis pengaruh pelatihan terhadap iklim organsiasi Mendiskripsikan dan menganalisis pengaruh pelatihan UKM dan iklim organisasi terhadap kinerja UKM melalui inovasi produk.

\section{Kerangka Pemikiran}

Kinerja merupakan salah satu indikator yang dapat melihat hasil dari proses pekerjaan tertentu, secara terencana pada waktu dan tempat dari karyawan serta organisasi bersangkutan Hubeis (2007). Arti penting dari kinerja adalah hasil kerja yang dapat dicapai seseorang atau sekelompok orang dalam suatu organisasi/instansi, sesuai dengan wewenang dan tanggung jawab masing-masing dalam upaya mencapai tujuan yang ingin di capai bersangkutan secara legal, tidak melanggar hukum dan sesuai dengan moral maupun etika (Sedarmayanti 2007). Ditambahkan oleh (Mangkunegara 2007) Faktor-faktor yang dapat mempengaruhi pencapaian kinerja adalah Faktor kemampuan (ability) dan faktor motivasi (motivation). Selain itu tujuan dari kinerja adalah untuk meningkatkan produktifitas usaha secara komprehensip dan terukur.

Untuk melihat kinerja dari anggota UKM Fashion di Kota Semarang, dengan menempatkan pelatihan dan iklim organisasi sebagai variabel bebasnya, 
selanjutnya diukur seberapa besar inovasi mempengaruhi pelatihan dan iklim organisasi terhadap kinerja. Berangkat dari pengertian diatas penelitian ini akan mengukur dan menganalisis pengaruh pelatihan dan iklim organisasi terhadap kinerja melalui inovasi sebagai variabel interveningnya, lebih jelas dapat dilihat pada Ilustrasi Kerangka Pemikiran berikut :

Ilustrasi 1. Kerangka Pemikiran Penelitian

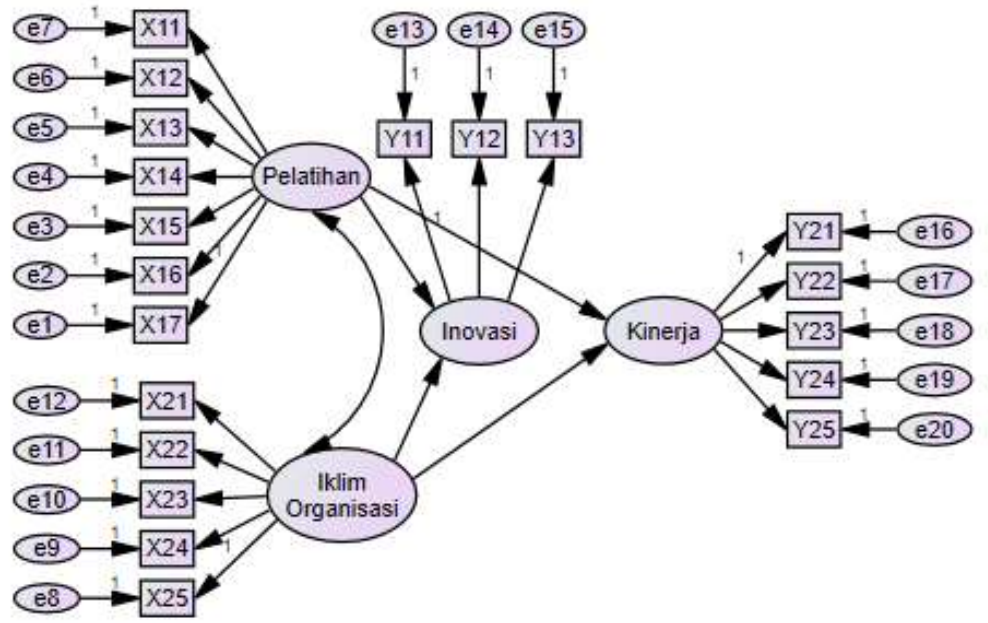

\section{METODE PENELITIAN}

\section{Jenis Penelitian}

Jenis penelitian ini adalah Explanatory Research, yaitu untuk memperjelas hubungan antar variabel-variabel penelitian dan menguji hipotesis yang telah dirumuskan dengan pendekatan kuantitatif (Singarimbun,2004). Hubungan variabel yang akan diungkap dalam penelitian ini Pengaruh Pelatihan, Iklim organisasi untuk meningkatkan Kinerja melalui Inovasi produk

\section{Populasi Penelitian dan Teknik Pengampilan Sampel Populasi Penelitian}

Populasi adalah keseluruhan karakteristik atau unit hasil pengukuran yang menjadi objek penelitian atau populasi merupakan objek atau subjek yang berada pada suatu wilayah yang memenuhi syarat-syarat tertentu berkaitan dengan masalah penelitian Sudjana (2001). Populasi dalam penelitian ini adalah seluruh anggota UKM industri kreatif fashion di Kota Semarang

\section{Teknik Pengambilan Sampel}

Dalam penelitian ini, responden penelitian yang digunakan adalah wirausahawan dan pekerja pada UKM industri kreatif fashion

Sampel adalah bagian dari jumlah dan karakteristik yang dimiliki oleh populasi Sudjana (2001). Teknik pengambilan sampel dalam penelitian ini dengan metode purpossive sampling, dengan kterteria sebagai berikut :

1. Telah menjalankan usaha lebih dari tiga (3) tahun 
2. Memiliki karyawan minimal 3 orang.

Penetapan kriteria-kriteria diatas didasarkan pada kelayakan responden yang dijadikan sebagai sample penelitian. Dimana UKM yang sudah menjalankan usahanya minimal 3 tahun merupakan UKM yang telah memiliki pengalaman dalam menjalankan usahanya. Hal serupanya bagi UKM yang sudah memiliki minimal 3 karyawan, sudah memiliki pengalaman dan sudah berdinamisasi dalam menjalankan usahanya, untuk melihat iklim organisasi.

Elemen penelitian mempunyai probalitas (kemungkinan) yang sama untuk dipilih. Jumlah UKM Fashion tahun 2018 sebanyak 50 pelaku usaha, namun yang memenuhi syarat sesuai kreteria yang sudah ditentukan sebanyak 45 dengan masing-masing UKM Fashion memiliki minimal 3 karyawan sehingga populasi yang diambil sebagai sampel sebanyak $3 \times 45 \mathrm{UKM}=135$ orang.

\section{Metode Pengumpulan Data}

1. Wawancara adalah melakukan komunikasi dua arah kepada responden UKM Industri Fashion Kota Semarang dengan bantuan kuesioner atau daftar pertanyaan.

2. Kuesioner kepada UKM Industri Kreatif Fashion Kota Semarang

3 . Data skunder diambil dari Dinas Perindustrian Kota Semarang. Berupa data produktifitas UKM Industri Kreatif Fashion.

\section{Metode Analisis Data}

Analisis data adalah interprestasi untuk penelitian yang ditujukan untuk menjawab pertanyaan-pertanyaan penelitian dalam rangka mengungkap fenomena sosial tertentu. Analisis data adalah proses penyederhanaan data kedalam bentuk yang lebih mudah dibaca dan di implementasikan. Analisa yang digunakan dalam penelitian adalah sebagai berikut :

\section{Analisa Deskriptif Kualitatif}

Analisa ini dilakukan untuk mendapatkan gambaran deskriptif mengenai responden penelitian ini, khususnya mengenai variabel-variabel penelitian yang digunakan (Ferdinand, 2006). Analisa ini dilakukan dengan menggunakan teknis analisa indeks untuk menggambarkan persepsi respondenatas item-item pertanyaan yang diajukan.

\section{Analisa Data Kuantitatif}

Metode analisa ini merupakan metode analisa yang dilakukan terhadap yang diperoleh dari hasil jawaban kuisioner digunakan untuk menganalisa data yang berbentuk angka-angka.

Teknik analisis digunakan untuk menginterpretasikan dan menganalisis data. Sesuai dengan model yang dikembangkan dalam penelitian ini maka alat analisis data yang digunakan adalah SEM (Structural Equation Modeling), yang dioperasikan melalui program AMOS (Ferdinand, 2006) .

Menggunakan tahapan pemodelan dan analisis persamaan struktural menjadi 7 langkah, yaitu :

Berikut ini penjelasan secara detail mengenai masing-masing tahapan :

\section{Pengembangan Model Berdasarkan Teori}

Langkah pertama dalam pengembangan model SEM adalah pencari atau pengembangan sebuah model yang mempunyai justifikasi terpenting yang kuat. Setelah itu, model tersebut divalidasi secara empirik melalui populasi program 
SEM. SEM tidak dipakai untuk menghasilkan hubungan kuasalitas. Tetapi untuk membenarkan adanya kausalitas teoritis melalui data uji empirik (Ferdinand, 2006). Model persamaan struktural didasarkan pada hubungan kausalitas, dimana perubahan satu variabel diasumsikan akan berakibat pada perubahan variabel lainnya. Kuatnya hubungan kausalitas antara 2 variabel yang diasumsikan peneliti bukan terletak pada metode analisis yang dipilih namun terletak pada justifikasi secara teoritis untuk mendukung analisis. Jadi jelas bahwa hubungan antar variabel dalam model merupakan deduksi dari teori. Tanpa dasar teoritis yang kuat SEM tidak dapat digunakan.

Menyusun Diagram Jalur dan Persamaan struktural (Langkah 2 dan 3)

Langkah berikutnya adalah menyusun hubungan kausalitas dengan diagram jalur dan menyusun persamaan struktural. Ada 2 hal yang perlu dilakukan yaitu menyusun model struktural yaitu dengan menghubungkan antar konstruk laten baik endogen maupun eksogen menyusun suatu dan menentukan model yaitu menghubungkan konstruk lahan endogen atau eksogen dengan variabel indikator atau manifest.

\section{HASIL PENELITIAN DAN PEMBAHASAN}

\section{Proses dan Hasil Analisis Data}

Pada bab ini disajikan gambaran data penelitian yang diperoleh dari hasil jawaban reponden, proses pengolahan data dan analisis hasil pengolahan data tersebut. Hasil pengolahan data selanjutnya akan digunakan sebagai dasar untuk analisis dan menjawab hipotesis penelitian yang diajukan. Analisis data diskriptif digunakan untuk menggambarkan kondisi jawaban responden untuk masingmasing variabel. Kuesioner yang diberikan kepada responden sebanyak 135 kuesioner. Jumlah jawaban responden yang bisa diteliti tersebut sudah memenuhi ketententuan sampel dalam penelitian ini yaitu menggunakan 134 responden. Hasil jawaban tersebut selanjutnya digunakan untuk mendapatkan tendensi jawaban responden mengenai kondisi masing-masing variabel penelitian.

Analisis data yang digunakan dalam penelitian ini adalah Structural Equation Modeling (SEM) dengan terlebih dahulu melakukan pengujian dimensi dimensinya dengan confirmatory factor analysis. Evaluasi terhadap model SEM juga akan dianalisis mendapatkan dan mengevaluasi kecocokan model yang diajukan. Setelah diketahui semua hasil pengolahan data, selanjutnya akan dibahas dan yang terakhir adalah menarik kesimpulan yang didasarkan pada hasil analisis tersebut.

Sebagaimana dijelaskan sebelumnya bahwa penelitian ini menerapkan analisis dengan Structural Equation Modelling (SEM) sebagai upaya pengujian hipotesis. Model teoritis dalam penelitian ini telah digambarkan pada bab III dimana model penelitian tersebut terdiri dari 20 indikator untuk menguji adanya hubungan kausalitas antara variabel-variabel yang dihipotesiskan.

Dalam analisis SEM terdapat dua metode penggunaan jenis matrik data input yang digunakan yaitu matrik varians/kovarians dan matriks korelasi. Analisis ini akan menggunakan input matriks kovarians untuk estimasi selanjutnya. Pemilihan input dengan matriks kovarian adalah karena matriks 
kovarian memiliki keuntungan dalam memberikan perbandingan yang valid antar populasi atau sampel yang berbeda, yang kadang tidak memungkinkan jika menggunakan model matriks korelasi. Masalah yang mungkin muncul adalah masalah mengenai ketidakmampuan model yang dikembangkan untuk menghasilkan estimasi yang unik. Gejala-gejala maslah identifikasi antara lain :

1. Standart error untuk satu atau beberapa koefisien adalah sangat besar.

2. Program tidak mampu menghasilkan matrik informasi yang seharusnya disajikan.

3. Muncul angka-angka yang ekstrim seperti adanya varians error yang negatif.

4. Muncul korelasi yang sangat tinggi antar koefisien estimasi yang didapat (misalnya lebih dari 0.9).

Apabila masalah-masalah tersebut muncul dalam analisis SEM, maka mengindikasikan bahwa data penelitian tidak mendukung model struktural yang dibentuk. Dengan demikian model perlu direvisi dengan mengembangkan teori yang ada untuk membentuk model yang baru.

Teknik estimasi yang akan digunakan dalam perhitungan SEM adalah dengan menggunakan maximum likelihood. Namun sebelum membentuk suatu full model SEM, terlebih dahulu akan dilakukan pengujian terhadap faktor-faktor yang membentuk masing-masiong variabel. Pengujian akan dilakukan dengan menggunakan model confirmatory factor analysis. Kecocokan model (goodness of fit), untuk confirmatory factor analysis juga akan diuji. Dengan program AMOS, ukuran-ukuran goodness of fit tersebut akan nampak dalam outputnya. Selanjutnya kesimpulan atas kecocokan model yang dibangun akan dapat dilihat dari hasil ukuran-ukuran goodness of fit yang diperoleh. Pengujian goodness of fit terlebih dahulu dilakukan terhadap model confirmatory factor analysis. Berikut ini merupakan bentuk analisis goodness of fit tersebut.

\section{Analisis Faktor Konfirmatori (Confirmatory Faktor Analysis)}

Analisis faktor konfirmatori ini merupakan tahap pengukuran terhadap dimensi-dimensi yang membentuk variabel laten dalam model penelitian. Variabel-variabel laten atau konstruk yang digunakan pada model penelitian ini terdiri dari 4 dengan jumlah seluruh dimensi berjumlah 20. Sebagaimana analisis faktor biasa, Tujuan dari analisis faktor konfirmatori adalah untuk menguji unidimensionalitas dari dimensi-dimensi pembentuk masing-masing variabel laten. Hasil analisis faktor konfirmatori dari masing masing model selanjutnya akan dibahas.

\section{Analisis Faktor Konfirmatori Kontruk Pelatihan UKM}

Variabel laten pelatihan pada model konfirmatori ini terdiri dari 7 indikator sebagai demensi pembentuknya, hasil pengolahan data untuk analisi faktor konfirmatori kontruk untuk pelatihan di tampilkan pada Gambar 1

\section{Gambar 1.}

\section{Analisis faktor Konfirmatori Kontruk Pelatihan UKM}

Chi Square $=13.301(\mathrm{df}=9)$

Prob $=.109$

RMSEA $=.053$

Chi square / $\mathrm{df}=1.478$

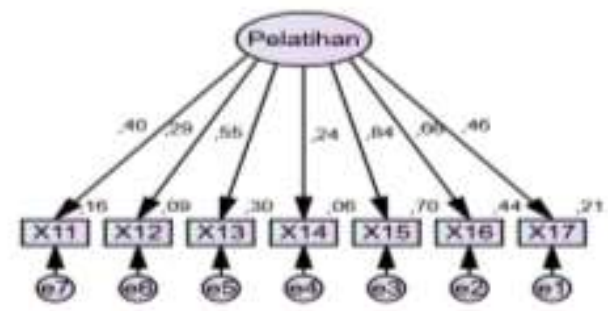


$\mathrm{GFI}=.967$

AGFI $=.924$

$\mathrm{TLI}=.980$

$\mathrm{CFI}=.988$

Sumber : Data primer yang diolah, 2018

Ringkasan hasil confirmatory faktor analysis dilihat bahwa semua kontruk yang digunakan untuk membentuk sebuah model penelitian, pada proses analisis faktor konfirmatori telah memenuhi kriteria goodness of fit yang telah ditetapkan. Nilai probability pengujian goodness of fit menunjukkan nilai 0.109 dengan pengujian-pengujian kelayakan model yang memenuhi syarat sebagai model yang baik.

Selain dari nilai probabilitay nilai RMSEA (The root Mean Square Error of Approximation), menunjukan bahwa kontruk penelitian ini dapat diterima dengan nilai RMSEA sebesar0.053 dimana nilai tersebut berada di antara 0.03 sampai 0.08. dengan demikian kecocokan model yang diprediksikan dengan nilainilai pengamatan cukup memenuhi kecocokan modelnya.

Untuk mendapatkan kemaknaan dari dimensi-dimensi yang terekstraksi dalam membentuk variabel laten, dapat diperoleh dari nilai standardized loading factor dari masing-masing dimensi. Jika diperoleh adanya nilai pengujian yang sangat signifikan maka hal ini mengindikasikan bahwa dimensi tersebut cukup baik untuk terekstraksi membentuk variabel laten. Hasil berikut merupakan pengujian kemaknaan masing-masing dimensi dalam membentuk variabel laten, untuk lebih jelads dapat dilihat pada tabel 1.

\section{Tabel 1}

Regression Weightspada Analisis faktor Konfirmatori Kontruk Pelatihan UKM

\begin{tabular}{|l|l|l|l|l|l|l|l|}
\hline & & & Estimate & S.E. & $\begin{array}{l}\text { Standardised } \\
\text { Estimate }\end{array}$ & C.R. & P \\
\hline X17 & $<---$ & Pelatihan & 1,025 &, 0234 &, 461 & 3,214 & $* * *$ \\
\hline X16 & $<---$ & Pelatihan & 1,515 &, 335 &, 662 & 4,526 & $* * *$ \\
\hline X15 & $<---$ & Pelatihan & 1,820 &, 386 &, 842 & 4,714 & $* * *$ \\
\hline X14 & $<---$ & Pelatihan &, 459 &, 201 &, 243 & 2,284 &, 022 \\
\hline X13 & $<---$ & Pelatihan & 1,316 &, 317 &, 554 & 4,150 & $* * *$ \\
\hline X12 & $<---$ & Pelatihan &, 578 &, 214 &, 289 & 2,704 &, 007 \\
\hline X11 & $<---$ & Pelatihan &, 855 &, 248 &, 400 & 3,442 & $* * *$ \\
\hline
\end{tabular}

Sumber : Data primer yang diolah, 2018

Analisis faktor tersebut juga menunjukkan nilai pengujian dari masing। masing pembentuk suatu konstruk. Hasil menunjukkan bahwa setiap indikatorindikator atau dimensi pembentuk masing-masing variabel laten menunjukkkan hasil baik, yaitu nilai dengan CR diatas 1,96. Dengan hasil ini, maka dapat dikatakan bahwa indikator-indikator pembentuk variabel laten telah menunjukkan unidimensionalitas. Selanjutnya berdasarkan analisis faktor konfirmatori konstruk ini, maka model penelitian dapat digunakan untuk analisis selanjutnya tanpa modifikasi atau penyesuaian-penyesuaian. 


\section{Analisis Faktor Konfirmatori Kontruk Iklim Organisasi}

Variabel laten ilkim organisasi pada model konfirmatori ini terdiri dari 5 indikator sebagai demensi pembentuknya, hasil pengolahan data untuk analisi faktor konfirmatori kontruk untuk iklim organisasi di tampilkan pada Gambar 2

\section{Gambar 2}

\section{Analisis faktor Konfirmatori Kontruk Iklim Organisasi}


Sumber : Data primer yang diolah, 2018

Ringkasan hasil confirmatory faktor analysis dilihat bahwa semua kontruk yang digunakan untuk membentuk sebuah model penelitian, pada proses analisis faktor konfirmatori telah memenuhi kriteria goodness of fit yang telah ditetapkan. Nilai probability pengujian goodness of fit menunjukkan nilai 0.394 dengan pengujian-pengujian kelayakan model yang memenuhi syarat sebagai model yang baik.

Selain dari nilai probabilitay nilai RMSEA (The root Mean Square Error of Approximation), menunjukan bahwa kontruk penelitian ini dapat diterima dengan nilai RMSEA sebesar0.073 dimana nilai tersebut berada di antara 0.03 sampai 0.08. dengan demikian kecocokan model yang diprediksikan dengan nilainilai pengamatan cukup memenuhi kecocokan modelnya.

Untuk mendapatkan kemaknaan dari dimensi-dimensi yang terekstraksi dalam membentuk variabel laten, dapat diperoleh dari nilai standardized loading factor dari masing-masing dimensi. Jika diperoleh adanya nilai pengujian yang sangat signifikan maka hal ini mengindikasikan bahwa dimensi tersebut cukup baik untuk terekstraksi membentuk variabel laten. Hasil berikut merupakan pengujian kemaknaan masing-masing dimensi dalam membentuk variabel laten, untuk lebih jelads dapat dilihat pada tabel 2

\section{Regression Weightspada Analisis faktor Konfirmatori Kontruk Iklim Organisasi}

\begin{tabular}{|l|l|l|l|l|l|l|l|l|}
\hline & & & Estimate & S.E. & $\begin{array}{l}\text { Standardised } \\
\text { Estimate }\end{array}$ & C.R. & P & Label \\
\hline X25 & $<-------$ & Iklim_Organisasi &, 210 &, 167 & 1.06 & 2,000 &, 045 & \\
\hline X24 & $<-------$ & Iklim_Organisasi &, 334 &, 167 &, 362 & 2,000 &, 045 & \\
\hline X23 & $<-------$ & Iklim_Organisasi &, 341 &, 170 &, 361 & 2,004 &, 045 & \\
\hline X22 & $<-------$ & Iklim_Organisasi &, 356 &, 085 &, 064 & 1,976 &, 505 & \\
\hline X21 & $<-------$ & Iklim_Organisasi &, 317 &, 129 &,- 213 & 1,981 &, 093 & \\
\hline
\end{tabular}

Sumber : Data primer yang diolah, 2018 
Analisis faktor tersebut juga menunjukkan nilai pengujian dari masing $\backslash$ masing pembentuk suatu konstruk. Hasil menunjukkan bahwa setiap indikatorindikator atau dimensi pembentuk masing-masing variabel laten menunjukkkan hasil baik, yaitu nilai dengan CR diatas 1,96. Dengan hasil ini, maka dapat dikatakan bahwa indikator-indikator pembentuk variabel laten telah menunjukkan unidimensionalitas. Selanjutnya berdasarkan analisis faktor konfirmatori konstruk ini, maka model penelitian dapat digunakan untuk analisis selanjutnya tanpa modifikasi atau penyesuaian-penyesuaian.

\section{Analisis Faktor Konfirmatori Kontruk Inovasi}

Variabel laten inovasi pada model konfirmatori ini terdiri dari 5 indikator sebagai demensi pembentuknya, hasil pengolahan data untuk analisi faktor konfirmatori kontruk untuk inovasi di tampilkan pada Gambar 3.

\section{Gambar 3.}

\section{Analisis faktor Konfirmatori Kontruk Inovasi}

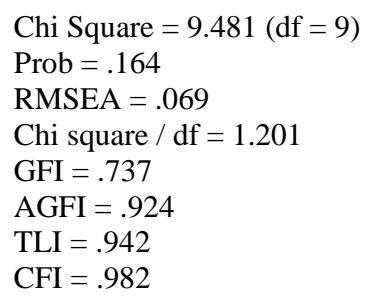

Sumber : Data primer yang diolah, 2018

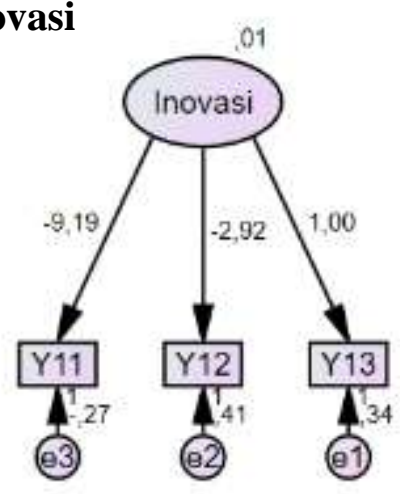

Ringkasan hasil confirmatory faktor analysis dilihat bahwa semua kontruk yang digunakan untuk membentuk sebuah model penelitian, pada proses analisis faktor konfirmatori telah memenuhi kriteria goodness of fit yang telah ditetapkan. Nilai probability pengujian goodness of fit menunjukkan nilai 0.164 dengan pengujian-pengujian kelayakan model yang memenuhi syarat sebagai model yang baik.

Selain dari nilai probabilitay nilai RMSEA (The root Mean Square Error of Approximation), menunjukan bahwa kontruk penelitian ini dapat diterima dengan nilai RMSEA sebesar0.069 dimana nilai tersebut berada di antara 0.03 sampai 0.08. dengan demikian kecocokan model yang diprediksikan dengan nilainilai pengamatan cukup memenuhi kecocokan modelnya.

Untuk mendapatkan kemaknaan dari dimensi-dimensi yang terekstraksi dalam membentuk variabel laten, dapat diperoleh dari nilai standardized loading factor dari masing-masing dimensi. Jika diperoleh adanya nilai pengujian yang sangat signifikan maka hal ini mengindikasikan bahwa dimensi tersebut cukup baik untuk terekstraksi membentuk variabel laten. Hasil berikut merupakan pengujian kemaknaan masing-masing dimensi dalam membentuk variabel laten, untuk lebih jelads dapat dilihat pada tabel 3 
Tabel 3

Regression Weightspada Analisis faktor Konfirmatori Kontruk Inovasi

\begin{tabular}{|l|l|l|l|l|l|l|l|l|}
\hline & & & Estimate & S.E. & $\begin{array}{l}\text { Starndardised } \\
\text { Estimate }\end{array}$ & C.R. & P & Label \\
\hline Y13 & $<------$ & Inovasi &, 290 &, 291 &, 1.00 & 1.863 &, 021 & \\
\hline Y12 & $<------$ & Inovasi &, 918 &, 301 & $-2,92$ & 1,963 &, 025 & \\
\hline Y11 & $<------$ & Inovasi &, 193 &, 271 & $-9,19$ & 1,986 &, 415 & \\
\hline
\end{tabular}

Sumber : Data primer yang diolah, 2018

Analisis faktor tersebut juga menunjukkan nilai pengujian dari masing\ masing pembentuk suatu konstruk. Hasil menunjukkan bahwa setiap indikatorindikator atau dimensi pembentuk masing-masing variabel laten menunjukkkan hasil baik, yaitu nilai dengan $\mathrm{CR}$ diatas 1,96. Dengan hasil ini, maka dapat dikatakan bahwa indikator-indikator pembentuk variabel laten telah menunjukkan unidimensionalitas. Selanjutnya berdasarkan analisis faktor konfirmatori konstruk ini, maka model penelitian dapat digunakan untuk analisis selanjutnya tanpa modifikasi atau penyesuaian-penyesuaian.

\section{Analisis Faktor Konfirmatori Kontruk Kinerja}

Variabel laten kinerja pada model konfirmatori ini terdiri dari 5 indikator sebagai demensi pembentuknya, hasil pengolahan data untuk analisi faktor konfirmatori kontruk untuk kinerja di tampilkan pada Gambar 4.

\section{Gambar 4.}

\section{Analisis faktor Konfirmatori Kontruk Kinerja}

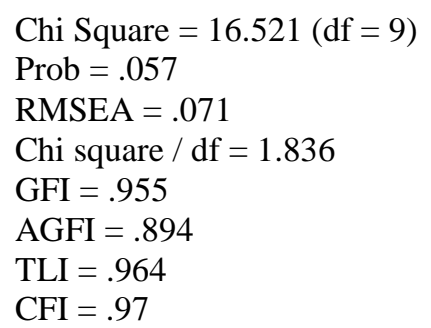

Sumber : Data primer yang diolah, 2

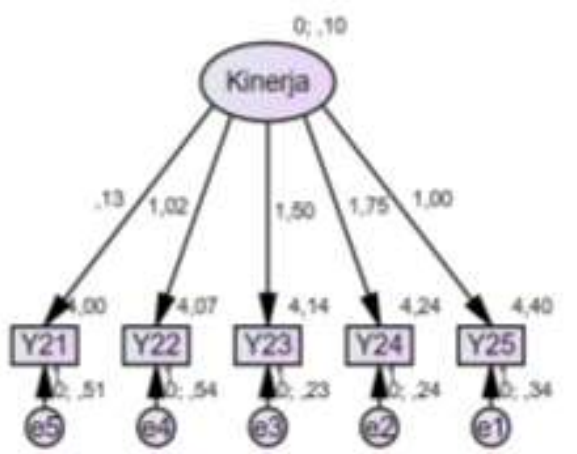

Ringkasan hasil confirmatory faktor analysis dılıhat bahwa semua kontruk yang digunakan untuk membentuk sebuah model penelitian, pada proses analisis faktor konfirmatori telah memenuhi kriteria goodness of fit yang telah ditetapkan. Nilai probability pengujian goodness of fit menunjukkan nilai 0.057 dengan pengujian-pengujian kelayakan model yang memenuhi syarat sebagai model yang baik.

Selain dari nilai probabilitay nilai RMSEA (The root Mean Square Error of Approximation), menunjukan bahwa kontruk penelitian ini dapat diterima 
dengan nilai RMSEA sebesar0.071 dimana nilai tersebut berada di antara 0.03 sampai 0.08. dengan demikian kecocokan model yang diprediksikan dengan nilainilai pengamatan cukup memenuhi kecocokan modelnya.

Untuk mendapatkan kemaknaan dari dimensi-dimensi yang terekstraksi dalam membentuk variabel laten, dapat diperoleh dari nilai standardized loading factor dari masing-masing dimensi. Jika diperoleh adanya nilai pengujian yang sangat signifikan maka hal ini mengindikasikan bahwa dimensi tersebut cukup baik untuk terekstraksi membentuk variabel laten. Hasil berikut merupakan pengujian kemaknaan masing-masing dimensi dalam membentuk variabel laten, untuk lebih jelads dapat dilihat pada tabel 4.

\section{Tabel 4.}

\section{Regression Weightspada Analisis faktor Konfirmatori}

Kontruk Kinerja

\begin{tabular}{|l|l|l|l|l|l|l|l|l|}
\hline & & & Estimate & S.E. & $\begin{array}{l}\text { Standardiset } \\
\text { Estimate }\end{array}$ & C.R. & P & Label \\
\hline Y25 & $<---$ & Kinerja & 1,620 &, 365 & 1.00 & $4 ., 367$ & $* * *$ & \\
\hline Y24 & $<---$ & Kinerja & 1,752 &, 403 & 1,75 & 4,351 & $* * *$ & \\
\hline Y23 & $<---$ & Kinerja & 1,502 &, 342 & 1.50 & 4,395 & $* * *$ & \\
\hline Y22 & $<---$ & Kinerja & 1,021 &, 305 & 1.02 & 3,353 & $* * *$ & \\
\hline Y21 & $<---$ & Kinerja &, 130 &, 225 &, 130 & 1,977 &, 564 & \\
\hline
\end{tabular}

Sumber : Data primer yang diolah, 2018

Analisis faktor tersebut juga menunjukkan nilai pengujian dari masing\ masing pembentuk suatu konstruk. Hasil menunjukkan bahwa setiap indikatorindikator atau dimensi pembentuk masing-masing variabel laten menunjukkkan hasil baik, yaitu nilai dengan CR diatas 1,96. Dengan hasil ini, maka dapat dikatakan bahwa indikator-indikator pembentuk variabel laten telah menunjukkan unidimensionalitas. Selanjutnya berdasarkan analisis faktor konfirmatori konstruk ini, maka model penelitian dapat digunakan untuk analisis selanjutnya.

\section{Analisi Struktural Equation Modelling (SEM)}

Analisis selanjutnya adalah analisis Structural Equation Model (SEM) secara full model, setelah dilakukan analisis terhadap tingkat unidimensionalitas dari indikator-indikator pembentuk variabel laten yang diuji dengan confirmatory factor analysis. Analisis hasil pengolahan data pada tahap full model SEM dilakukan dengan melakukan uji kesesuaian dan uji statistik. Hasil pengolahan data untuk analisis full model SEM ditampilkan pada Gambar 5 


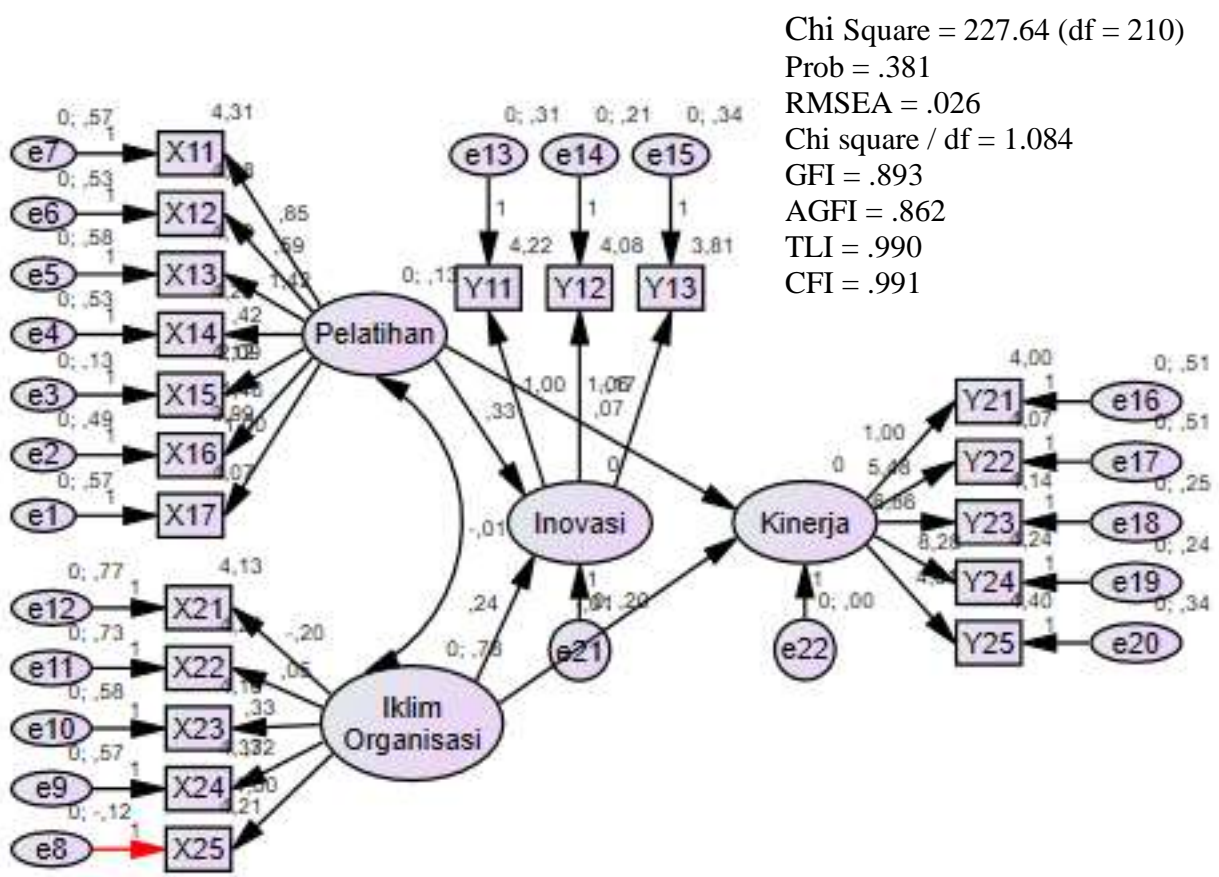

Gambar 5. hasil penelitian

Uji terhadap kelayakan full model SEM ini diuji dengan menggunakan Chi square, GFI, CFI, TLI, CMIN/DF dan RMSEA berada dalam rentang nilai yang diharapkan, meskipun AGFI diterima secara marginal, Hasil tersebut menunjukkan bahwa model yang digunakan dapat diterima.

Tingkat signifikansi sebesar 0,381 menunjukkan sebagai suatu model persamaan struktural yang baik. Indeks pengukuran TLI, CFI, CMIN/DF dan RMSEA berada dalam rentang nilai yang diharapkan meskipun GFI dan AGFI diterima secara marginal.

\section{Pengujian Evaluasi Nilai Residual}

Pada tahap ini akan dilakukan interpretasi model dan memodifikasi model yang tidak memenuhi syarat pengujian. Setelah model diestimasi, residualnya haruslah kecil atau mendekati nol dan distribusi frekwensi dari kovarian residual harus bersifat simetrik. Jika suatu model memiliki nilai kovarians residual yang tinggi maka, maka sebuah modifikasi perlu dipertimbangkan dengan catatan ada landasan teoritisnya. Bila ditemukan bahwa nilai residual yang dihasilkan oleh model itu cukup besar (>2.58), maka cara lain dalam memodifikasi adalah dengan mempertimbangkan untuk menambah sebuah alur baru terhadap model yang diestimasi itu. Data standardized residual covariances yang diolah dengan program AMOS dapat dilihat dalam lampiran.

\section{Pengujian Hipotesis}

Setelah semua asumsi dapat dipenuhi, selanjutnya akan dilakukan pengujian hipotesis sebagaimana diajukan pada bab sebelumnya. Pengujian 6 hipotesis penelitian ini dilakukan berdasarkan nilai Critical Ratio (CR) dari suatu hubungan kausalitas dari hasil pengolahan SEM sebagaimana pada tabel 5 berikut. 
Tabel 5

Regression Weight Structural Equational Model

\begin{tabular}{|l|l|l|l|l|l|l|}
\hline & & & Estimate & S.E. & C.R. & P \\
\hline Kinerja & $<---$ & Pelatihan &, 071 &, 087 & 3,814 &, 015 \\
\hline Kinerja & $<---$ & Iklim_Organisasi &, 013 &, 016 & 3,798 &, 025 \\
\hline Inovasi & $<---$ & Pelatihan &, 327 &, 170 & 1,976 &, 044 \\
\hline Inovasi & $<---$ & Iklim_Organisasi &, 236 &, 102 & 5,305 &, 021 \\
\hline Kinerja & $<---$ & Inovasi &, 017 &, 027 & 2,635 &, 026 \\
\hline Iklim_Organisasi & $<---$ & Pelatihan &, 014 &, 030 & 4,465 &, 042 \\
\hline
\end{tabular}

Sumber : Data primer yang diolah, 2018

Berdasarkan hasil analisis pada tabel 5 dapat dijelaskan nilai probabilitas semuanya dibawah 0.050 artinya bahwa semua variabel berpengaruh. Selanjutnya berdasarkan hasil analisis tersebut dapat dijelaskan bahwa pelatihan berpengaruh positif dan signifikan terhadap inovasi dan kinerja. Iklim organsiasi berpenagruh positif dan signifikan terhadap inovasi dan kinerja.

Analisis selanjutnya adalah analisis pengaruh variebel intervening, dalam penelitian ini variabel intervening adalah inovasi. Salah satu tujuan dari penelitian ini adalah melihat dan menganalisis pengaruh variabel intervening. Untuk melihat pengaruhnya pada penelitian ini menggunakan uji sobel test. Sobel test merupakan uji untuk mengetahui pengaruh variabel mediasi. Dalam penelitian ini pengaruh pelatihan, iklim organisasi terhadap kinerja melalui inovasi. Dengan rumus sebagai berikut menurut Hayes (2013) :

\section{$\mathbf{Z}=\mathbf{a} \mathbf{X} \mathbf{b} / \mathbf{S E a b}$}

Keterangan

Z : Pengaruh Mediasi

a : $\quad$ regression weight

Seab : $\quad$ o,018 Menurt hayer (2013)

Berdasarkan persamaa tersebut di dapatkan hasil bahwa seberapa besar inovasi dapat memediasi pelatihan dan iklim organisasi terhadap kinerja IKH Fashion di kot Semarang didapatkan hasilnya sebagai berikut :

Uji Hipotesis Sobel test pertama : $\quad$ Uji hipotesis sobel test kedua :

$$
\begin{array}{ll}
Z=\mathbf{a} X \text { b /Seab } & Z=\mathbf{a} X \text { b /Seab } \\
Z=0.044 \times 0.026 / 0.018 & Z=0.021 \times 0.026 / 0.018 \\
Z=0.063 & Z=0.030
\end{array}
$$

Berdasarkan hasil analisis sobel test dapat di tarik kesimpulan bahwa nilai hasil perhitungan inovasi memediasi pelatihan terhadap kinerja nilainya 0.063 dan inovasi memediasi iklim organisasi terhadap kinerja nilainya 0.30 sehingga dapat dijelaskan bahwa nilai tersebut untuk hipotesis ke 7 melebihi dari nilai $\mathrm{P}$ sebesar 0.05 yang sudah di tetapkan pada bab sebelumnya, namun untuk Hipotesis 8 lebih kecil dari nilai tersbut. Sehingga dapat ditarik kesimpulan bahwa inovasi tidak memediasi pelatihan terhadap kinerja, namun inovasi memediasi iklim organisasi terhadap kinerja. 


\section{KESIMPULAN DAN IMPLIKASI \\ Kesimpulan}

Berdasarkan hasil analisis dan pembahasan diatas, maka dapat ditarik kesimpulan dalam penelitian ini, untuk menjawab semua hipotesis hipotesis yang ada di bab sebelumnya. Kesimpulan dari penelitian ini antara lain :

1. H1 Pelatihan UKM berpengaruh positif dan signifikan terhadap kinerja UKM. Dimana semakin sering dilakukan pelatihan yang tepat sasaran, maka semakin meningkat kinerja dari pelaku UKM Fashion di Kota Semarang.

2. H2 Iklim Organisasi berpengaruh positif dan signifikan terhadap kinerja UKM, berdasarkan penelitian ini semakin baik pengelolaan iklim organisasi, maka semakin meningkat kinerja dari anggota UKM Fashion di Kota Semarang.

3. H3 Pelatihan UKM berpengaruh positif dan signifikan terhadap inovasi produk, berdasarkan hasil penelitian dapat disimpulkan bahwa semakin sering dilakukan pelatihan yang dibutuhkan oleh pelaku UKM, semakin baik inovasi produk dari anggota UKM Fashion di Kota Semarang.

4. H4 Iklim organisasi berpengaruh positif dan signifikan terhadap inovasi produk, hasil penelitian ini dapat disimpulkan bahwa semakin baik pengelolaan iklim organisasi, maka semakin meningkat inovasi produk dari pelaku UKM Fashion di Kota Semarang .

5. H5 Inovasi produk berpengruh positif dan signifikan terhadap kinerja UKM, kesimpulan yang dapat tarik dari penelitian ini adalah semakin baik inovasi produk yang dilakukan oleh pelaku UKM, maka semakin meningkat kinerja UKM Fashion di Kota Semarang.

6. H6 Pelatihan UKM berpengaruh positif dan signifikan terhadap iklim organisasi, dimana semakin sering dilaksanakan pelatihan yang dapat meningkatkan kedewasaan anggota UKM fashion, maka semakin baik pengelolaan iklim organisasi dalam kelompok UKM fashion di Kota Semarang.

7. Inovasi produk tidak memediasi pelatihan UKM terhadap kinerja. Namun inovasi memdiasi iklim organisasi terhadap kinerja UKM. Hal tersebut dapat dilihat dari hasil uji sobel test dengan menggunakan perhitungan persamaan. Dapat disimpulkan bahwa inovasi produk tidak memediasi, disebabkan karena pelatihan UKM dan iklim organisasi secara terpisah mampu meningkatkan kinerja UKM Fashion di Kota Semarang.

\section{Implikasi Kebijakan}

Berdasarkan hasil analisis dan kesimpulan diatas dapat dirumuskan implikasi kebijakan yang dapat dilakukan oleh Pemerintah Kota Semarang khususnya Dinas Perindustrian Kota Semarang tentang hasil penelitian ini adalah :

Kebijakan yang dapat dilakukan dari Pelatihan UKM meningkatkan kuantitas dan kualitas pelatihan dengan mempertimbangkan : 1. Jenis Pelatihan, 2. Tujuan pelatihan, 3. Materi Pelatihan., 4. Metode pelatihan, 5. Kualifiaksi Peserta, 
6. Kualifiaksi pelatih, 7. Waktu pelaksanaan. Selain dari meningkatkan kualitas pemerintah perlu ikut dalam menjaga iklim organisasi yang dapat mempengaruhi kinerja UKM, dimana Pemerintah Kota Semarang, dalam hal ini Dinas Perindustrian diharapkan mampu menjaga stabilitas Iklim organisasi selalu mengedukasi pelaku UKM yang meliputi dari : 1. Tanggungjawab , 2. Kehangatan organisasi dan 3. Saling mendukung sesama karyawan dan pelaku UKM fashion di Kota Semarang.

Pelatihan UKM dapat mempengaruhi inovasi produk, hal tersebut menunjukan bahwa pelatihan UKM akan memampu meningkatkan inovasi produk, sehingga Pemerintah Kota Semarang, diharapkan mampu meningkatkan pelatihan, melihat pelatihan sebagai prioritas peningkatan inovasi produk dan kinerja UKM. Pelatihan dapat dilakukan dengan melihat : 1. Jenis pelatihan yang dilaksanakan harus mengikuti tranding kekinian dan 2. Waktu melaksanakan kegiatan harus sesuai dengan momentum yang terjadi . sehingga pelatihan bisa langsung mampu meningkatkan inovasi produk. Pemerintah Kota Semarang, dalam hal ini Dinas Perindustrian harus memandang penting bahwa inovasi produk akan mampu meningkatkan kinerja UKM. Inovasi produk yang dilakukan dapat dilihat dari 1. Perubahan inovasi produk melalui perubahan dan pengayaan desain produk, 2. Inovasi teknis, baik pemasaran maupun manajemen pengelolaan, 3. Pengembangan produk dalam UKM fashion di Kota Semarang.

\section{Keterbatan Penelitian}

Keterbatasan yang terjadi dalam penelitian ini merupakan, kelemahan yang terjadi baik secara teoritis maupun secara operasional. Keterbatasan penelitian secara teori yaitu terdapat beberapa indikator dari variabel mendekati ambang batas. Secara operasional adalah lokasi pelaku UKM fashion di Kota Semarang yang tersebar di wilayah Kota Semarang, sehingga butuh waktu untuk menyebar quetioner kepada responden. Selain dari itu ada pelaku UKM yang masih pemula, yang mengakibatkan standar yang ditentukan minimal 3 tahun agak sedikit kesulitan.

\section{DAFTAR PUSTAKA}

AA. Anwar Prabu Mangkunegara, 2013, Manajemen Sumber Daya Manusia Perusahaan, Remaja Rosdakarya, Bandung.

Achmad, S. Ruky. 2003. Kualitas Sumber Daya Manusia. Jakarta: PT Gramedia Pustaka Utama

Agusty Ferdinand, 2012, Metode Penelitian Manajemen, Badan. Penerbit Universitas Diponegoro. Semarang.

Alam, A. Hamdani, Dodi Hermana. 2008. Classroom Action Reasearch.: Rahayasa.

Angelica, Diana ; Cahyani, Ria. 2009. Pemasaran Dasar, Edisi 16. Jakarta : Salemba Empat.

Anwar Prabu Mangkunegara. 2005. Sumber Daya Manusia perusahaan. Remaja Rosdakarya: Bandung. 
Anthi. M.H , Suarman, Ngadlan (2015). Pengaruh Tingkat Satuan Pendidikan dan Pelatihan terhadap Kinerja Karyawan PT Bank Riau KEPRI Kantor Pusat Pekanbaru.

Ardianto, Elvinaro, Soemirat Soleh. 2008. Dasar-Dasar Public Relation.

Davis, Keith dan Newstrom, 2000, Perilaku Dalam Organisasi, Edisi ketujuh, Penerbit Erlangga, Jakarta.

Dessler, G. (2008). Manajemen Sumber Daya Manusia. Edisi 11. Alih Bahasa. Jakarta: PT Indeks.

Drucker, Peter, F. (1986), Innovation and Etrepreneurship. London : Heinemann, Edisi Indonesia.

Fontana, Avanti.2011. Innovate We Can!. Bekasi : Cipta Inovasi Sejahtera.

Ghozali, Imam. 2011. "Aplikasi Analisis Multivariate Dengan Program SPSS". Semarang: Badan Penerbit Universitas Diponegoro.

Gomes, Faustino Cardoso. 2002. Manajemen Sumber Daya Manusia. Yogyakarta: Andi.

Hamel, 2006. Competing for the Future, USA : Harvard Bussiness School Press.

Handoko, 2010, Manajemen Personalia \& Sumberdaya Manusia, Edisi kedua, BPFE UGM Yogyakarta

Handoko, T Hani. 2001. Manajemen Personalia dan Sumberdaya Manusia,Edisi Kedua. BPFE, Yogyakarta.

Mangkuprawira. S dan Aida V. Hubeis. (2007) Manajemen Mutu Sumber Daya Manusia. Ghalia INDONESIA. Bogor.

Hasibuan, Malayu S.P., 2011. Manajemen Sumber Daya Manusia. Bumi Aksara, Jakarta

Herman Sofyandi, 2008, Manajemen Sumber Daya Manusia, Edisi Pertama, Penerbit Graha Ilmu, Yogyakarta.

Octaviana Panambunan, Bernhard Tewal dan Irvan Trang (2017). Work Experience, Job Training, Organizational Climate And Its Impact On Employee Performance Pt. Pln (Persero) Suluttenggo Region

Pearce II, John A. dan Robinson Richard B.Jr. (2009). Manajemen Strategis 10. Salemba Empat : Jakarta.

Regina. J.K, Lucky O.H, Dotulong (2015) Pengaruh Pendidikan, Pelatihan, Dan Inovasi Terhadap Kinerja Pegawai Badan Pelaksana Penyuluhan Dan Ketahanan Pangan Kota Manado. Jurnal Emba 331 Vol.3 No.3 Sept. 2015, Hal.331-340.

Rivai \& Basri, 2004: 14 Penilaian Kinerja. diakses dari http://jurnalsdm.blogspot.com/ diakses pada tanggal 9 oktober 2011.

Rivai, Veithzal. (2011). Manajemen Sumber Daya Manusia Untuk Perusahaan Dari Teori Ke Praktek. PT. RAJAGRAFINDO PERSADA, Jakarta.

Robbins, P Stephen, 2008, Perilaku Organisasi, Terjemahan Diana Angelica; Jakarta: Salemba .

Sastrohadiwiryo, Siswanto. 2009. Manajemen Tenaga Kerja Indonesia. Bandung : Bumi Aksara.

Sedarmayanti, 2007, Sumber Daya Manusia dan Produktivitas Kerja, Bandung, Penerbit Mandar Maju. 
Sedarmayanti, 2009, Manajemen Sumber Daya Manusia, Reformasi Birokrasi dan Manajemen Pegawai Negeri Sipil, Bandung, Refika Aditama.

Setiyawan, Budi dan Waridin. 2006. Pengaruh Disiplin Kerja Karyawan Dan Budaya Organisasi Terhadap Kinerja Di Divisi Radiologi RSUP Dokter Kariadi Semarang. JRBI. Vol 2. No 2. Hal: 181-198.

Simamora, 2014, Membuat Karyawan Lebih Produktif Dalam Jangka Panjang(Manajemen SDM). STIE YKPN, Yogakarta.

Simanjuntak, Payaman J. 2005. Manajemen dan Evaluasi Kinerja. Jakarta: FE UI. Simanjuntak, Payaman, J. 2002. Undang-Undang yang Baru tentang Serikat Pekerja/Serikat Buruh. Kantor Perburuhan Internasional: Jakarta

Simanjuntak, Payaman, J. 2001. Ekonomi Sumber Daya Manusia. Lembaga Penerbit Fakultas Ekonomi Universitas Indonesia: Jakarta.

Smith, P. L., dan Ragan, T. J. (1993). Instructional Design. New York : Merril. Sudjana. D (2007) Manajemen dan Sistem Pelatihan. Bandung: Falah Production. Sudjana. D (2006) Evaluasi Program Pendidikan Luar Sekolah. Bandung: PT. Rosda.

Sudjana. D (2001) Metode dan Teknik Pembelajaran Partisipatif, Bandung: Falah Production.

Sudjana. D (2004) Pendidikan Nonformal. Bandung: Falah Production.

Sulaefi. (2017) Pengaruh Pelatihan Dan Pengembangan erhadap Disiplin Kerja Dan Kinerja Karyawan. jurnal manajemen kewirausahaan JMDK vol 5 no 1.

Suluttenggo (2017). Pengalaman Kerja, Pelatihan Kerja, Iklim Organisasi Dan Pengaruhnya Terhadap Kinerja Pegawai PT. Pln (Persero) Wilayah / Jurnal Emba Vol.5 No.2 Juni 2017, Hal. 2183 - 2192

Suci Rahmadewi, Rizky Fauzan (2013). Pengaruh Iklim Organisasi dan Kepuasan Kerja terhadap Kinerja Karyawan

Tambunan, Tulus, T.H. 2002. Usaha Kecil dan Menengah di Indonesia Beberapa Isu Penting. Jakarta :PT Salemba Empat.

Taufiq Effendi (2005). Permenpan No PER/66/M.PAN/2005 Tentang Jabatan Fungsional Widyaisuara dan Angka kreditnya, Jakarta: Menpan.

Vosen, robert W (1998), Relative Strength and Weaknesses of Small Firm in Innovation, International Small Business Journal, 11. pp. 1-24

Yoder, Dale. (1981) Personal Management And Industrial Relation. New Delhi: Prentice-Hall of India Private Limited. 